\title{
Efficacy of bacterin-, outer membrane protein- and fimbriae extract-based vaccines for the control of Salmonella Enteritidis experimental infection in chickens ${ }^{1}$
}

\author{
Márcia C. Menão ${ }^{2,3}$, Claudete S. Astolfi-Ferreira ${ }^{3}$, Terezinha Knöbl ${ }^{3}$ \\ and Antonio J. Piantino Ferreira ${ }^{3 *}$
}

\begin{abstract}
Menão M.C., Astolfi-Ferreira C.S., Knöbl T. \& Ferreira A.J.P. 2013. Efficacy of bacterin-, outer membrane protein- and fimbriae extract-based vaccines for the control of Salmonella Enteritidis experimental infection in chickens. Pesquisa Veterinária Brasileira 33(3):326-330. Departamento de Patologia, Faculdade de Medicina Veterinária e Zootecnia, Universidade de São Paulo, Av. Prof. Dr. Orlando Marques de Paiva 87, São Paulo, SP 05508 270, Brazil. E-mail: ajpferr@usp.br

The efficacy of three vaccines was evaluated in chickens for the control of experimental infection with Salmonella Enteritidis (SE) phage type 4. The vaccines were produced with bacterin, outer membrane proteins (OMP) and fimbriae crude extract (FE). The chickens were vaccinated intramuscularly with two doses of each vaccine at 12 and 15 weeks of age. The chickens were then orally challenged with $10^{9} \mathrm{CFU} /$ chicken Salmonella Enteritidis phage type 4 at 18 weeks of age. Fecal swabs were performed for the recovery of shedding SE, and SE was recovered from the liver and spleen. Additionally, antibody titers were measured in the serum by micro-agglutination test. The results indicated that the vaccine produced with bacterin yielded better results and resulted in reduction of fecal shedding and organ invasion by SE after oral challenge, although no vaccine was $100 \%$ effective for the control of SE experimental infection.
\end{abstract}

INDEX TERMS: Salmonella Enteritidis, vaccine, bacterin, fimbriae, outer membrane protein, chicken.

RESUMO.- [Eficácia de bactéria inativada (bacterina), proteína da membrana externa e extrato de fimbrias no controle de infecção experimental por Salmonella Enteritidis (SE) em galinhas.] A eficácia de três vacinas de Salmonella Enteritidis fagotipo 4, produzidas na forma de bacterina, proteínas de membrana externa (OMP) e extrato bruto de fímbrias (FE) foi avaliada para proteção de aves infectadas experimentalmente. As aves foram vacinadas por via intramuscular com duas doses de cada vacina as 12 e 15 semanas de idade e desafiadas com $10^{9}$ UFCs de Salmonella Enteritidis fagotipo 4 às 18 semanas de idade, por via oral. A eficácia foi determinada através do reisolamento da bactéria nas fezes e no fígado e baço, e os anticor-

\footnotetext{
${ }^{1}$ Received on November 16, 2012.

Accepted for publication on February 5, 2013.

${ }^{2}$ Instituto de Ciências da Saúde, Universidade Paulista (UNIP). Rua Dr. Bacelar 1212, Vila Clementino, São Paulo, SP 04026-002, Brazil.

${ }^{3}$ Faculdade de Medicina Veterinária e Zootecnia, Universidade de São Paulo (USP), Av. Dr. Orlando Marques de Paiva 87, São Paulo, SP 05508 270.*Corresponding author: ajpferr@usp.br
}

pos foram mensurados no soro. Os resultados demonstraram que a vacina produzida com a bacterina foi mais eficaz em comparação às outras vacinas examinadas, para reduzir a excreção fecal e a invasão de órgãos após o desafio por SE.

TERMOS DE INDEXAÇÃO: Salmonella Enteritidis, vacina, bacterina, fímbrias, proteínas da membrana externa, galinha.

\section{INTRODUCTION}

Salmonella spp., responsible for large economic losses, are a serious global public health issue. Salmonella Enteritidis (SE) is often isolated from human foodborne poisoning outbreaks, and a great majority of cases are associated with the consumption of products of avian origin, particularly eggs (Humphrey 2006).

Salmonella contamination typically occurs by the oral route. These bacteria quickly infect lymphoid tissues, including Peyer's patches and enterocytes in the intestinal mucosa (Revolledo et al. 2006). The mechanisms of invasion have not yet been fully elucidated; however, it is known that Salmonella can infect CD18-expressing macropha- 
ges and that the infection occurs after systemic bacterial translocation from the gut lumen into the blood circulation (Vasquez-Torres et al. 1999). This is followed by the colonization of organs, with strong tropisms for liver, spleen and bone marrow (Zhang-Barber et al. 1999). The route of SE inoculation may affect the pattern of spread to the organs.

To avoid poultry contamination by Salmonella spp. and to reduce the levels of human food poisoning, vaccination could be an important preventive strategy to breed birds with sanitary measures typically used by the poultry industry. Limitations associated with the use of vaccines in avian salmonellosis control include the induction of partial protection in the case of inactivated vaccines, possibly due to antigen destruction during preparation (Barrow 2007), and risk of virulence reversal caused by insufficient attenuation in the case of live-attenuated vaccines (Lee et al. 2007).

Different subunits have been used to stimulate the immune response; particularly fimbriae extract (FE) and outer membrane proteins (OMPs) (Barrow 2007). Fimbriae are thread-like structures involved in the process of attachment to the surface of eukaryotic cells and may contribute to bacterial pathogenicity (Ibarra \& Steele-Mortimer 2009). Outer membrane proteins are also involved in bacterial adhesion and assist in the iron production process, host cell invasion, and resistance to serum bactericidal activity (Ochoa-Repáraz et al. 2005).

The objective of this study was to compare the efficacy of vaccines produced with bacterin, OMPs or FE of Salmonella Enteritidis (SE) phage type 4. The vaccines were administered by a parenteral route, and the protection of chicken was determined through an oral challenge with heterologous SE strains.

\section{MATERIALS AND METHODS}

\section{Chickens}

Ten chickens of 12-week-old SPF (specific pathogen free) White Leghorn female chickens obtained from Laboratory Bio Vet (Vargem Grande Paulista, SP, Brazil) were used in this study. The chickens were free of Salmonella spp. and were given commercial diet and water ad libitum. The animals in these experiments were maintained according to the Committee on Care and Use of Laboratory Animal Resources of the School of Veterinary Medicine of University of São Paulo (FMVZ-USP), Brazil, protocol \#2671/2012.

\section{Bacteria}

Salmonella Enteritidis (SE) phage type 4 (PT4) strain 10/22 was isolated from chicken and was used for immunogenic vaccine preparations. SE PT4 strain 15/10, which is resistant to Nalidixic acid $\left(\mathrm{Nal}^{\mathrm{R}} 100 \mu \mathrm{g} / \mathrm{mL}\right)$, was used as the challenge strain. These strains belong to the Laboratory of Ornitopathology, FMVZ-USP, and were stored in Luria Bertani broth containing 20\% glycerol at $-80^{\circ} \mathrm{C}$.

\section{Vaccine preparation}

Bacterial culture and extracts. SE PT4 strain 10/22 and SE PT4 strain $15 / 10 \mathrm{Nal}^{\mathrm{R}}$ were grown on MacConkey agar at $37^{\circ} \mathrm{C}$ for 24 hours. One colony was transferred to CFA (Colonization Factor Agar) broth, pH 7.4, and incubated at $37^{\circ} \mathrm{C}$ for 24 hours. The bacterial suspension was then transferred to Roux bottles containing
CFA agar and incubated for 24 hours at $37^{\circ} \mathrm{C}$. The bacteria were harvested in $0.1 \mathrm{M}$ PBS, pH 7.4. SE PT4 strain 10/22 was inactivated with $0.5 \%$ formaldehyde for bacterin preparation (Melamed et al. 1991).

Bacterin Vaccine. Bacterin was prepared according to description above and bacterial suspensions were done with $0.1 \mathrm{M}$ PBS, pH 7. Bacterial suspensions were previously centrifuged at $6,300 \mathrm{x}$ g for 15 minutes at $4^{\circ} \mathrm{C}$. and bacterial concentration was adjusted to $10^{8} \mathrm{CFU} / 0.5 \mathrm{~mL}$ vaccine preparation (Melamed et al. 1991).

Fimbriae Extract Vaccine. For obtaining the fimbriae extract (FE), the bacterial suspension was subjected to blender mechanical extraction (Sorvall, Newport Pagnell, England) at $4^{\circ} \mathrm{C}$ for 5 minutes and was centrifuged at $6,300 \mathrm{x}$ g for 20 minutes at $4^{\circ} \mathrm{C}$. The supernatant was filtered through a $0.45-\mu \mathrm{M}$ Millipore filter and concentrated by $85 \%$ ammonium sulfate precipitation in an ice bath. The solution was then centrifuged at $12,700 \mathrm{x} \mathrm{g}$, and the precipitate was extensively dialyzed against $0.85 \% \mathrm{NaCl}$. The antigen protein concentration was then determined using the bicinchoninic acid method (Smith et al. 1985). Two vaccines were prepared with the FE at concentrations of $0.2 \mathrm{mg} / 0.5 \mathrm{~mL} / \mathrm{bird}$ and $0.8 \mathrm{mg} / 0.5 \mathrm{~mL} / \mathrm{bird}$.

Outer Membrane Protein Vaccine. The pellet obtained after centrifugation of the mechanically extracted product was stored in a blender for further preparation of the OMP vaccine according to the method of Achtman et al. (1983). The bacteria were resuspended in 0.1 M PBS, pH 7.4, and were then centrifuged at 2,057 $\mathrm{x}$ $\mathrm{g}$ for $20 \mathrm{~min}$. The pellet was then resuspended in $10 \mathrm{mM}$ Tris- $\mathrm{HCl}$, pH 7.8. This procedure was repeated twice. After the last centrifugation, the pellet was resuspended in $10 \mathrm{mM}$ Tris- $\mathrm{HCl}, \mathrm{pH} 8.0$. The bacteria were sonicated for 80 s on the $50 \%$ duty cycle at $4^{\circ} \mathrm{C}$ and then centrifuged at $2,057 \mathrm{x}$ g for $20 \mathrm{~min}$ at $4^{\circ} \mathrm{C}$. The cell pellets containing unbroken bacteria were discarded, and the supernatant was centrifuged at 20,000rpm in a Beckman ultracentrifuge (SW-28 rotor) for $60 \mathrm{~min}$ at $4^{\circ} \mathrm{C}$. The pellet was resuspended in $10 \mathrm{mM}$ Tris- $\mathrm{HCl}, \mathrm{pH} 8.0$, and frozen at $-20^{\circ} \mathrm{C}$. After freezing for 1 $\mathrm{h}$, the sample was resuspended in $30 \mathrm{~mL} 11.1 \mathrm{mM}$ Tris- $\mathrm{HCl}$, pH 7.6, containing $1.67 \%$ sarkosyl. The sample was incubated at room temperature for $20 \mathrm{~min}$ and then centrifuged at 20,000 rpm in a Beckman ultracentrifuge (SW-28 rotor) for $90 \mathrm{~min}$ at $20^{\circ} \mathrm{C}$. The protein concentration was determined by the micro BCA (bicinchoninic acid) method (Smith et al. 1985). Three different concentrations of this vaccine were prepared: each $0.5 \mathrm{~mL}$ containing 1,2 , or $4 \mathrm{mg}$ of the antigen (Table 1 ). An aluminum hydroxide adjuvant was added to all vaccines at final concentration of $0.22 \%$ (Fesce \& Agnes 1967).

\section{Experimental design}

The birds were divided in eight (8) random groups and intramuscularly vaccinated in the breast muscle at 12 and 15 weeks of age, as shown in Table 1. The oral challenge was performed with the SE PT4 strain 15/10 $\mathrm{Nal}^{\mathrm{R}}$ (heterologous to vaccine strain) at a concentration of $10^{9} \mathrm{CFU} /$ bird 21 days after the second vaccine dose (bird age at 18 weeks). The chickens were observed daily for clinical signs, such as apathy, somnolence, and diarrhea and mortality. At 14 and 21 days after the first vaccination, 14 and 21 days after the second vaccination, and 14 and 21 days after challenge, the birds were bled to obtain serum for antibody measurement using the micro-agglutination test (Williams \& Whittemore 1971).

\section{Micro-Agglutination Test to detect serum antibodies (MA Test)}

The test was performed in U-bottom microplates with $100 \mu \mathrm{L}$ serum diluted in $100 \mu \mathrm{L} 0.1 \mathrm{M}$ PBS, pH 7.4. The sera were serially 
Table 1. Experimental study design: SPF chickens vaccinated with different types of Salmonella Enteritidis vaccine and then challenged

\begin{tabular}{|c|c|c|c|c|c|c|}
\hline $\begin{array}{l}\text { Group } \\
\mathrm{n}=10\end{array}$ & Treatments & Concentration & $\begin{array}{c}\text { Vaccine } \\
\text { dose }\end{array}$ & $\begin{array}{c}\text { Age at } 1^{\text {st }} \\
\text { vaccination } \\
\text { (weeks) }\end{array}$ & $\begin{array}{c}\text { Age at } 2^{\text {nd }} \\
\text { vaccination } \\
\text { (weeks) }\end{array}$ & $\begin{array}{c}\text { Age at oral } \\
\text { challenge } \\
\text { (weeks) }\end{array}$ \\
\hline $\mathrm{T} 1$ & Non-vaccinated, non-challenged & - & - & - & - & - \\
\hline $\mathrm{T} 2$ & Non-vaccinated, SE-challenged & - & - & - & - & 18 \\
\hline T3 & OMP & $1 \mathrm{mg} / \mathrm{bird}$ & $0.5 \mathrm{~mL}$ & 12 & 15 & 18 \\
\hline $\mathrm{T} 4$ & OMP & $2 \mathrm{mg} / \mathrm{bird}$ & $0.5 \mathrm{~mL}$ & 12 & 15 & 18 \\
\hline $\mathrm{T} 5$ & OMP & $4 \mathrm{mg} / \mathrm{bird}$ & $0.5 \mathrm{~mL}$ & 12 & 15 & 18 \\
\hline T6 & $\mathrm{FE}$ & $0.2 \mathrm{mg} / \mathrm{bird}$ & $0.5 \mathrm{~mL}$ & 12 & 15 & 18 \\
\hline $\mathrm{T} 7$ & $\mathrm{FE}$ & $0.8 \mathrm{mg} / \mathrm{bird}$ & $0.5 \mathrm{~mL}$ & 12 & 15 & 18 \\
\hline $\mathrm{T} 8$ & Bacterin & $10^{8} \mathrm{UFC} / \mathrm{bird}$ & $0.5 \mathrm{~mL}$ & 12 & 15 & 18 \\
\hline
\end{tabular}

diluted at a ratio of $1: 2$. Next, $100 \mu \mathrm{L}$ of antigen that was obtained by concentration of the bacterial pellet was added. The optical density was 0.190 , which was measured with an ELISA reader (Multiskan Reader, Vienna, VA, USA) at $540 \mathrm{~nm}$. The plates were incubated at $37^{\circ} \mathrm{C}$ for $24 \mathrm{~h}$. The MA test results were read with the aid of inverted mirror, and reaction were interpreted as follows: positive reaction, a well revealing no antigen button forming an agglutination shaped mesh-like in U-shaped micro plate button; negative reaction, a well with a large distinct button corresponding to the negative control (Williams \& Whittemore 1971).

\section{Salmonella shedding}

Cloacal swabs were obtained from all birds daily for 7 days after challenge, and also at day 14 and day 21 after challenge. On the $21^{\text {st }}$ day after challenge, all of the birds were sacrificed by cervical dislocation. The cecum, spleen and liver were removed aseptically for bacteriological examination. The swabs were cultured in $9 \mathrm{~mL}$ tetrathionate (Difco, Detroit, ML, USA) and incubated for $24 \mathrm{~h}$ at $37^{\circ} \mathrm{C}$. The broth culture was streaked on XLT4 agar (Difco, Detroit, ML, USA) containing $100 \mathrm{mg} / \mathrm{mL}$ of Nalidixic acid (Sigma, St Louis, MO, USA) followed by incubation for $24 \mathrm{~h}$ at $37^{\circ} \mathrm{C}$. Each organ was macerated in sterile plastic bags and then added to the tetrathionate broth at a ratio of $1: 10$. The samples were then incubated for $24 \mathrm{~h}$ at $37^{\circ} \mathrm{C}$. An aliquot $(0.1 \mathrm{~mL})$ of each sample was cultivated on XLT4 agar containing $100 \mathrm{mg} / \mathrm{mL}$ Nalidixic acid and incubated for $24 \mathrm{~h}$ at $37^{\circ} \mathrm{C}$. After incubation, representative black colonies that were characteristic of Salmonella were confirmed biochemically and serologically (Ferreira et al. 2003).

\section{Statistical analysis}

Statistical analysis was performed with the Wilcoxon-Mann-Whitney U test using SPSS software for Windows, version 9.0 (SPSS Chicago, Illinois, USA). The differences between groups were considered significant when $\mathrm{p}<0.05$.

\section{RESULTS}

All groups were positive for Salmonella Enteritidis (SE). The groups varied in the number of bacteria and days until bacterial detection after the oral challenge, as determined by the cloacal swabs (Table 2). However, in groups T7 (0.8mg/bird fimbriae) and T8 (bacterin/0.5mL/bird), significant reductions $(\mathrm{p}<0.05)$ in the elimination of SE in the feces compared to the positive controls were observed. Group T7 $(0.8 \mathrm{mg} /$ bird of FE) recovered from infection by $30 \%$, which was the lowest rate. Groups T3 (1 mg OMP / bird) and T8 (bacterin $/ 0.5 \mathrm{~mL} /$ bird) recovered from in-
Table 2. Salmonella Enteritidis recovered from cloacal swabs of chickens vaccinated with different treatments and then challenged

\begin{tabular}{|c|c|c|c|c|c|c|c|c|c|c|c|c|}
\hline \multirow[t]{2}{*}{ Group } & \multirow[t]{2}{*}{ Vaccine } & \multicolumn{9}{|c|}{ Days after challenge } & \multirow{2}{*}{$\begin{array}{c}\mathrm{N}^{0} \text { positive } / \\
\text { total birds }\end{array}$} & \multirow{2}{*}{$\begin{array}{c}\% \\
\text { positive }\end{array}$} \\
\hline & & 1 & 2 & 3 & 4 & 5 & 67 & & & 21 & & \\
\hline $\mathrm{T} 1$ & $\begin{array}{l}\text { Non-vaccinated, } \\
\text { non-challenged }\end{array}$ & - & - & - & - & - & - & & - & - & $0 / 10$ & $0 \%$ \\
\hline $\mathrm{T} 2$ & $\begin{array}{l}\text { Non-vacinated, } \\
\text { SE-challenged }\end{array}$ & 3* & 2 & 1 & 1 & 3 & -6 & & - & - & $9 / 10$ & $90 \%$ \\
\hline T3 & OMP $1 \mathrm{mg} /$ bird & 3 & - & - & - & 1 & - - & & - & - & $4 / 10$ & $40 \%$ \\
\hline $\mathrm{T} 4$ & OMP $2 \mathrm{mg} /$ bird & 7 & - & - & - & 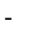 & - - & & - & - & $7 / 10$ & $70 \%$ \\
\hline T5 & OMP $4 \mathrm{mg} /$ bird & 4 & 2 & 1 & 1 & 1 & -2 & & 2 & - & $6 / 10$ & $60 \%$ \\
\hline T6 & FE $0.2 \mathrm{mg} / \mathrm{bird}$ & 4 & 1 & 1 & - & - & 31 & & 4 & - & $6 / 10$ & $60 \%$ \\
\hline T7 & FE $0.8 \mathrm{mg} / \mathrm{bird}$ & 1 & 1 & - & - & 1 & - - & & 1 & - & $3 / 10$ & $30 \%$ \\
\hline T8 & $\begin{array}{l}\text { Bacterin } 10^{8} \text { UFC/ } \\
\text { bird }\end{array}$ & - & 2 & 1 & 1 & - & 11 & & 1 & - & $4 / 10$ & $40 \%$ \\
\hline
\end{tabular}

*The number of birds from which Salmonella Enteritidis was re-isolated when the cloacal swabs were collected and analyzed.

fection by $40 \%$. The reduction of fecal excretion in these groups was statistically significant $(\mathrm{p}<0.05)$ compared to the positive control group that was orally challenged but not vaccinated. The highest rate of recovery $(70 \%)$ was in Group T4 (2 mg/bird of OMP).

Re-isolation of SE from the organs of the orally challenged birds was positive for all groups and was dependent on the number of birds that recovered from infection and the type of organ. Groups T4 (2mg/bird/0.5mL of OMP), T5 (4mg/bird/0.5mL of OMP) and T8 (bacterin $/ 0.5 \mathrm{~mL} /$ bird) scored $10 \%$ re-isolation rates, which were the lowest rates observed and were statistically significant $(\mathrm{p}<0.05)$ compared to the positive control groups. Groups T3 $(1 \mathrm{mg} /$ bird $/ 0.5 \mathrm{~mL}$ of OMP) and T7 ( $0.8 \mathrm{mg} / \mathrm{bird} / 0.5 \mathrm{~mL}$ of FE) scored 30\% SE isolation rates; these rates were the highest (Table 3). Of the harvested organs, the cecum had highest number of SE isolations $(n=7)$.

The micro agglutination tests indicated that all of the vaccines induced antibody responses to SE in the birds. Twenty-one days after the first and second vaccinations, the highest mean antibody titers occurred in all the groups, although increases in mean titers 14 days after the second vaccination were observed in Groups T3 $(1 \mathrm{mg} / \mathrm{bird} / 0.5 \mathrm{~mL}$ of OMP) and T8 (bacterin/0.5mL/bird). Group T5 (4mg/ bird $/ 0.5 \mathrm{~mL}$ of OMP) exhibited equal mean titers at 14 and 21 days after the second vaccination. Bacterin induced the 
Table 3. Recovery of Salmonella Enteritidis from organs after vaccination and challenge of the chickens with a heterologous Salmonella strain

\begin{tabular}{|c|c|c|c|c|c|c|}
\hline \multirow[t]{2}{*}{ Group } & \multirow[t]{2}{*}{ Vaccine } & \multicolumn{3}{|c|}{$\begin{array}{c}\text { Number of positive } \\
\text { chickens in each group }\end{array}$} & \multirow[t]{2}{*}{$\begin{array}{l}\mathrm{N}^{\circ} \text { positive/ } \\
\text { total birds }\end{array}$} & \multirow[t]{2}{*}{$\begin{array}{c}\% \\
\text { positive }\end{array}$} \\
\hline & & Cecum & Liver & Spleen & & \\
\hline $\mathrm{T} 1$ & $\begin{array}{l}\text { Non-vaccinated, } \\
\text { non-challenged }\end{array}$ & - & - & - & $0 / 10$ & 0 \\
\hline $\mathrm{T} 2$ & $\begin{array}{l}\text { Non-vaccinated, } \\
\text { SE-challenged }\end{array}$ & 1 & 2 & 2 & $5 / 10$ & $50 \%$ \\
\hline T3 & OMP 1 mg/bird & 1 & - & 2 & $3 / 10$ & $30 \%$ \\
\hline $\mathrm{T} 4$ & OMP 2 mg/bird & - & - & 1 & $1 / 10$ & $10 \%$ \\
\hline T5 & OMP $4 \mathrm{mg} /$ bird & 1 & - & - & $1 / 10$ & $10 \%$ \\
\hline T6 & $\mathrm{FE} 0.2 \mathrm{mg} / \mathrm{bird}$ & - & 1 & 1 & $2 / 10$ & $20 \%$ \\
\hline $\mathrm{T} 7$ & FE $0.8 \mathrm{mg} / \mathrm{bird}$ & 3 & - & - & $3 / 10$ & $30 \%$ \\
\hline T8 & $\begin{array}{l}\text { Bacterin } 10^{8} \mathrm{UFC} / \\
\text { bird }\end{array}$ & 1 & - & - & $1 / 10$ & $10 \%$ \\
\hline
\end{tabular}

highest levels of antibody titers in the vaccinated birds. In Group T8 (bacterin/0.5mL/bird), the highest mean antibody titers were detected 21 days after the first vaccination and 14 days after the second vaccination.

The highest mean antibody titers after the oral challenge were achieved during the second week, except for Group T6 $(0.2 \mathrm{mg} / \mathrm{bird} / 0.5 \mathrm{~mL}$ of FE). In this group, the peak antibody titer occurred during the third week. Group T7 $(0.8 \mathrm{mg} / \mathrm{bird} / 0.5 \mathrm{~mL}$ of FE) displayed the highest mean titer, and Group T6 displayed the lowest.

\section{DISCUSSION}

Different types of salmonella vaccines have been used in chickens to immunize and protect against excretion of salmonella; however, complete protection against the elimination of highly infectious serotypes immediately after challenge has not yet been achieved (Nassar et al. 1994, Freitas Neto et al. 2008, Atterbury et al. 2009, Revolledo \& Ferreira 2010).

Salmonella Enteritidis (SE), when experimentally inoculated by the oral route, colonizes the intestines of chickens, and a high percentage of the SE can usually be recovered in the feces over the following two weeks. The percentage of SE then declines, although some strains can persist in the intestinal tract for several months. SE shedding is also directly related to the dose and route of inoculation used for the experimental infection (Purchase et al. 2008, Barrow et al. 1990).

In this study, the vaccines did not prevent SE fecal excretion in birds when orally challenged; however, the $0.8 \mathrm{mg}$ $\mathrm{FE} /$ bird vaccine, the $1 \mathrm{mg}$ OMP/bird vaccine and bacterin induced significant reductions $(\mathrm{p}<0.05)$ in SE excretion in the feces compared to the control group. The results of this study are consistent with Gast et al. (1993), who studied laying chicken vaccinated with two SE bacterins, phage type 13a, followed by oral challenge two weeks after the second vaccination. The authors reported partial protection, with more than $50 \%$ of the vaccinated birds shedding Salmonella during the first week after challenge. The bacteria persisted in the bird droppings for only two weeks after the challenge, and after this period, no re-isolation was observed.
The vaccines used also reduced the number of SE isolations in the organs of the orally challenged birds; however, none of the vaccines completely eliminated the bacteria. The group immunized with OMP at concentrations of 2 and $4 \mathrm{mg} / \mathrm{bird}$ showed the same reduction ratios of Salmonella as the group vaccinated with bacterin. However, these groups had high rates of SE re-isolation in the fecal swabs. Because these birds had already presented with an established intestinal microbiota, this could have been a factor for Salmonella infection (Revolledo et al. 2003). It is known that colonization of the intestinal tract with a mixture of bacteria, which can produce volatile fatty acids, plays an important role in the prevention of Salmonella infection (Mead 2000, Revolledo et al. 2009).

The activation of a Salmonella-specific immune response is important for the elimination of these bacteria. Because Salmonella are facultative intracellular pathogens that invade phagocytic cells of the liver and spleen, the activation of cell-mediated immunity is required to promote the destruction of Salmonella-infected cells. When these bacteria are found outside the eukaryotic cell, the antibodies can act by opsonization and phagocytosis, among other mechanisms, to eliminate the bacteria (Revolledo et al. 2006).

The relationship between the immune response and protection is demonstrated by the results obtained with bacterin, as the birds that received this vaccine displayed higher antibody titers than the birds that received the other vaccines. Bacterin also showed significant differences $(p<0.05)$ in the reduction of SE recovery in both the feces and organs compared to the orally challenged control group.

Vaccines consisting of fimbriae did not induce high antibody titers in the birds. Similarly, vaccines consisting of outer membrane proteins at concentrations of 2 and $4 \mathrm{mg} /$ bird also did not stimulate high antibody titers; rather, they did result in significant reductions in the isolation of SE in the organs of the orally challenged group $(p<0.05)$ compared to the control group. Chart \& Rowe (1991) demonstrated that antibodies against the outer membrane proteins of SE phage type 4 were not involved in the protection of experimentally infected mice after vaccination. The correlation between the levels of Salmonella-specific antibodies and protection against Salmonella colonization is not always applicable (Bouzoubaa 1987, Gast \& Beard 1992, Beal \& Smith 2007).

Desmidt et al.. (1998) evaluated the role of antibodies in the immune response of bursectomized birds and control birds against experimental infection with SE phage type 4 by examining fecal excretion and organ invasion by the bacteria. They found that fecal excretion was significantly lower in birds of the control group compared to the bursectomized group 13 days after inoculation, and SE re-isolation in the cecum decreased during the following weeks. They also observed reductions in the numbers of bacteria in the spleen and liver between 2 and 3 weeks. Antibodies for SE reached maximum titers two weeks after inoculation. These results indicate that SE elimination depends, in part, on humoral immunity. For SE elimination, the intestinal IgG/IgA response was more effective than the systemic response. 


\section{CONCLUSIONS}

The results obtained under these experimental conditions indicate that the vaccines reduced the fecal excretion and organ colonization of Salmonella Enteritidis in poultry to different extents.

Bacterin was more effective at protecting the chickens than the fimbriae and outer membrane protein vaccines.

The vaccine protection was not $100 \%$ effective against SE experimental infection in chickens, but currently use is recommended to reduce SE shedding during production of chicken in the poultry production worldwide.

\section{REFERENCES}

Achtman M., Mercer A., Kusecek B., Heuzenroeder M., Aaronson W., Sutton A. \& Silver R.P. 1983. Six widespread bacterial clones among Escherichia coli $\mathrm{K} 1$ isolates. Infect. Immun. 39:315-335.

Atterbury R.J., Carrique-Mas J.J., Davies R.H. \& Allen V.M. 2009. Salmonella colonization of laying following vaccination with killed and live attenuated commercial Salmonella vaccines. Vet. Rec. 17:493-496.

Barrow P.A., Hassan J.O. \& Berchieri Jr A. 1990. Reduction in fecal excretion of Salmonella typhimurium strain F98 in chickens vaccinated with live and killed S. typhimurium organisms. Epidemiol. Infect. 104:413-426.

Barrow P.A. 2007. Salmonella infections: immune and non-immune protection with vaccines. Avian Pathol. 36:1-13.

Beal R.K. \& Smith A.L. 2007. Antibody response to Salmonella: its induction and role in protection against avian enteric salmonelosis. Expert. Rev. Anti. Infect. Ther. 5:873-881.

Bouzoubaa K., Nagaraja K.V., Newman J.A. \& Pomeroy B.S. 1987. Use of membrane proteins from Salmonella gallinarum for prevention of fowl typhoid infection in chickens. Avian Dis. 31:699-704.

Chart H. \& Rowe B. 1991. Antibodies to lipopolysaccharide and outer membrane proteins of Salmonella enteritidis PT4 are not involved in protection from experimental infection. FEMS Microbiol. Lett. 84:345350 .

Desmidt M., Ducatelle R., Mast J., Godderis B.K. \& Haesebrouck F. 1998. Role of the humoral immune system in Salmonella enteritidis phage type four infection in chickens. Vet. Immunol. Immunopathol. 63:355-367.

Fesce A. \& Agnes F. 1967. Comparative study on the adjuvant action of bacterial endotoxins. II. Evaluation of the effect of the following adjuvants administered to mice by subcutaneous injection: Freund, endotoxins, zymosan, aluminum hydroxide, alone or associated with endotoxins or zymosan. Arch. Vet. Ital. 18:401-414.

Ferreira A.J., Ferreira C.S., Knobl T., Moreno A.M., Bacarro M.R., Chen M., Robach M. \& Mead G.C. 2003. Comparison of three commercial competitive-exclusion products for controlling Salmonella colonization of broilers in Brazil. J. Food Prot. 66:490-492.

Freitas Neto O.C., Mesquita A.L., Paiva J.B., Zotesso F. \& Berchieri Jr A. 2008. Control of Salmonella enterica serovar Enteritidis in laying by inactivated Salmonella Enteritidis vaccines. Braz. J. Microbiol. 39:390-396.

Gast R.K., Stone H.D. \& Holt P.S. 1993. Evaluation of the efficacy of oil-emul- sion bacterins for reducing fecal shedding of Salmonella enteritidis by laying hens. Avian Dis. 37:1085-1091.

Gast R.K. \& Beard C.W. 1992. Evaluation of a chick mortality model for predicting the consequences of Salmonella enteritidis infections in laying hens. Poult. Sci. 71:281-287.

Humphrey T.J. 2006. Are happy chickens safer chickens?: poultry welfare and disease susceptibility. Brit. Poult. Sci., 47:379- 390.

Ibarra J.A. \& Steeler-Mortimer O. 2009. Salmonella, the ultimate insider: Salmonella virulence factors that modulate intracellular survival. Cell. Microbiol. 11:1579-1586.

Lee Y.J., Mo I.P. \& Kang M.S. 2007. Protective efficacy of live Salmonella gallinarum $9 \mathrm{R}$ vaccine in commercial layer flocks. Avian Pathol. 36:495-498.

Mead G.C. 2000. Prospects for competitive treatment to control salmonellas and other foodborne pathogens in poultry. Vet. J. 159:111-123.

Melamed D., Leitner G. \& Heller E.D. 1991. A vaccine against avian colibacillosis based on ultrasonic inactivation of Escherichia coli. Avian Dis. 35:17-22.

Nassar T.J., Al-Nakhli H.M. \& Al-Ogaliv Z.H. 1994. Use of live and inactivated Salmonella enteritidis phage type 4 vaccines to immunize laying hens against experimental infection. Rev. Sci. Tech. 13:855-867.

Ochoa-Repáraz J., Garcia B., Solano C., Lasa I., Irache J.M. \& Gamazo C. 2005. Protective ability of subcellular extracts from Salmonella enteritidis and from a rough isogenic mutant against salmonelosis in mice. Vaccine 10:1491-1501.

Purchase C., Picard J., McDonald R. \& Bisschop S.P. 2008. A comparison on the oral application and injection routes using the onderstepoort biological products fowl typhoid vaccine, its safety, efficacy and duration of protection in commercial laying hens. J. South Afr. Vet. Med. Assoc. 79:39-43.

Revolledo L., Ferreira C.S.A. \& Ferreira A.J.P. 2003. Comparison of experimental competitive-exclusion cultures for controlling Salmonella colonization in broiler chicks. Braz. J. Microbiol. 34:354-358.

Revolledo L., Ferreira, A.J.P. \& Mead G.C. 2006. Prospects in Salmonella Control: competitive exclusion, probiotics, and enhancement of avian intestinal immunity. J. App. Poult. Res. 15:341-351

Revolledo L, Ferreira C.S. \& Ferreira A.J. 2009. Prevention of Salmonella Typhimurium colonization and organ invasion by combination treatment in broiler chicks. Poult. Sci. 88:734-743.

Revolledo L. \& Ferreira A.J. 2010. Salmonella antibiotic-mutant strains reduce fecal shedding and organ invasion in broiler chicks. Poult. Sci. 89:2130-2140.

Smith P.K., Krohn R.I., Hermanson G.T., Mallia A.K., Gartner F.H., Provenzano M.D., Fujimoto E.K., Goeke N.M., Olson B.J. \& Klenk D.C. 1985. Measurement of protein using bicinchoninic acid. Anal. Biochem. 150:76-85.

Vazquez-Torres A., Jones-Carson J., Bäumler A.J., Falkow S., Valdivia R., Brown W., Le M., Berggren R., Parks W.T. \& Fang F.C. 1999. Extraintestinal dissemination of Salmonellla by CD18-expressing phagocytes. Nature 401:804-808.

Williams J.E. \& Whittemore A.D. 1971. Serological diagnosis of pullorum disease with the micragglutination system. Appl. Microbiol. 21:394-399.

Zhang-Barber L., Turner A.K. \& Barrow P.A. 1999. Vaccination for control of Salmonella in poultry. Vaccine 17:2538-2545. 